\title{
Membangun Masyarakat Mandiri di Masa Pandemi COVID-19 Melalui Pelatihan Akutansi Biaya Produk dan Teknik Pemasaran Digital
}

\author{
Desti Fitriati ${ }^{1}$, Nur Yulianti Hidayah ${ }^{2}$, Febri Maspiyanti ${ }^{3}$ \\ ${ }^{1,3}$ Program Studi Teknik Informatika, Fakultas Teknik, Universitas Pancasila \\ ${ }^{2}$ Program Studi Teknik Industri, Fakultas Teknik, Universitas Pancasila \\ e-mail: desti.fitriati@univpancasila.ac.id ${ }^{1}$, nurhidayah@univpancasila.ac.id ${ }^{2}$, \\ febri.maspiyanti@univpancasila.ac.id ${ }^{3}$
}

\begin{abstract}
The Corona pandemic has made almost all people carry out activities from home, be it school or work matters. Not a few companies have terminated their employment or laid off their workers. This also caused the Indonesian financial system to become unstable and the wheels of the Indonesian economy experienced a decline. To stabilize this financial system, steps that can be taken are creating a new business opportunity as an alternative income. The proposed new business opportunities are also in line with the characteristics of Micro, Small and Medium Enterprises (MSMEs), where MSMEs play an important role in the economy in Indonesia. Even so, there are still some internal and external obstacles that must be faced by MSME actors. One of the internal barriers that will be the main focus to be raised is Human Resources (HR) including a lack of knowledge about the latest production technology and how to carry out quality control of products, the lack of ability to read market needs is still not sharp, so it is not able to properly grasp the needs desired by the market, and product marketing still relies on simple mouth to mouth marketing. To overcome the various problems above, counseling and workshops were carried out on cost accounting training and digital marketing techniques, where this topic was taken so that MSME players and people who were just starting a business due to being affected by COVID-19 gain insight into how to control and record production costs, and can reach a wider market share with more attractive promotional designs and digital marketing technology.
\end{abstract}

Keywords: Corona, COVID-19, Cost Accounting, Digital Marketing Techniques, MSMEs

\begin{abstract}
Abstrak
Pandemi Corona membuat hampir semua masyarakat melakukan kegiatan dari rumah, baik itu urusan sekolah maupun pekerjaan. Tidak sedikit pula perusahaan yang melakukan Pemutusan Hubungan Kerja (PHK) maupun merumahkan para pekerjanya. Hal ini pula yang menyebabkan sistem keuangan Indonesia menjadi tidak stabil dan roda perekonomian Indonesia mengalami penurunan. Untuk menstabilkan sistem keuangan ini, maka langkah yang bisa dilakukan adalah membuat sebuah peluang usaha baru sebagai alternatif pendapatan. Peluang usaha baru yang diusulkan ini juga sejalan dengan karakteristik Usaha Mikro, Kecil dan Menengah (UMKM), dimana UMKM memiliki peranan penting dalam perekonomian di Indonesia. Meskipun demikian, masih terdapat beberapa hambatan internal maupun eksternal yang harus dihadapi pelaku UMKM. Salah satu hambatan internal yang menjadi fokus utama yang akan diangkat adalah Sumber Daya Manusia (SDM) meliputi kurangnya pengetahuan mengenai teknologi produksi terbaru dan cara menjalankan quality control terhadap produk, kurangnya kemampuan membaca kebutuhan pasar masih belum tajam, sehingga belum mampu menangkap dengan cermat kebutuhan yang diinginkan pasar, dan pemasaran produk masih mengandalkan cara sederhana mouth to mouth marketing (pemasaran dari mulut ke mulut). Untuk mengatasi berbagai permasalahan di atas maka dilakukanlah kegiatan penyuluhan dan workshop tentang pelatihan akuntansi biaya dan teknik pemasaran digital, dimana topik ini diambil agar pelaku UMKM maupun masyarakat yang baru memulai usaha karena terdampak COVID-19 mendapatkan wawasan tentang cara mengendalikan dan mencatat biaya produksi, serta dapat menjangkau pangsa pasar yang lebih luas dengan desain promosi yang lebih menarik dan teknologi digital marketingnya.
\end{abstract}

Kata kunci: Corona, COVID-19, Akuntansi Biaya, Teknik Digital Marketing, UMKM

\section{PENDAHULUAN}

Pandemi Corona membuat hampir semua masyarakat melakukan kegiatan dari rumah, baik itu urusan sekolah maupun pekerjaan. Sebanyak kurang lebih 1 milyar siswa di seluruh 
dunia melakukan pembelajaran secara daring karena di-nonaktifkannya kegiatan belajarmengajar secara tatap muka (Mondol \& Mohiuddin, 2020). Tidak sedikit pula perusahaan yang melakukan Pemutusan Hubungan Kerja (PHK) maupun merumahkan para pekerjanya (CNBC, 2020). Hal ini pula yang menyebabkan sistem keuangan Indonesia menjadi tidak stabil dan roda perekonomian Indonesia mengalami penurunan. Keterpurukan menghadapi wabah Covid 19 dapat diselesaikan yaitu dengan meningkatkan kesejahteraan bagi ekonomi bisnis lokal (Pakpahan, 2020).

Sebagai seorang akademisi yang memiliki kemampuan Hardskill yang baik, maka diperlukannya kontribusi untuk membantu agar roda tersebut terus berjalan. Dalam hal ini solusi yang diberikan adalah memberikan penyuluhan maupun workshop sebagai tambahan wawasan dan modal untuk memiliki usaha kreatif yang dapat dikembangkan. Usaha kreatif ini pula dapat menjadi peluang usaha baru agar masyarakat tetap dapat menghasilkan uang meskipun berada dirumah. Usaha kreatif ini sebagai peluang usaha baru juga merupakan salah satu bentuk kewirausahaan. Dengan demikian pendekatan kewirausahaan dapat diimplementasikan sebagai upaya membangun pondasi ekonomi. Kewirausahaan juga tidak hanya fokus kepada seberapa besar input yang digunakan, namun lebih kepada bagaimana menggunakan potensi yang ada untuk menciptakan output bagi kesejarteraan ekonomi (Rahmi, ismanto, \& Fathoni, 2020)

Peluang usaha baru yang diusulkan ini juga sejalan dengan karakteristik Usaha Mikro, Kecil dan Menengah (UMKM), dimana UMKM memiliki peranan penting dalam perekonomian di Indonesia (Sarifah, Atmaja, dan Verawati, 2019). Beberapa peran penting UMKM dalam perekonomian Indonesia adalah kedudukannya sebagai pemain utama dalam kegiatan ekonomi di berbagai sektor, yaitu: penyedia lapangan kerja yang terbesar; pemain penting dalam pengembangan kegiatan ekonomi lokal dan pemberdayaan masyarakat; pencipta pasar baru dan sumber inovasi; serta sumbangannya dalam menjaga neraca pembayaran melalui kegiatan ekspor. Meskipun demikian, masih terdapat beberapa hambatan internal maupun eksternal yang harus dihadapi pelaku UMKM. Salah satu hambatan internal yang menjadi fokus utama yang akan diangkat adalah Sumber Daya Manusia (SDM). Berdasarkan data dari Lembaga Pengembangan Perbankan Indonesia dan Bank Indonesia (LPPI dan BI, 2015) , Hambatan dari sisi SDM meliputi:

- Kurangnya pengetahuan mengenai teknologi produksi terbaru dan cara menjalankan quality control terhadap produk.

- Kemampuan membaca kebutuhan pasar masih belum tajam, sehingga belum mampu menangkap dengan cermat kebutuhan yang diinginkan pasar.

- Pemasaran produk masih mengandalkan cara sederhana mouth to mouth marketing (pemasaran dari mulut ke mulut). Belum menjadikan media sosial atau jaringan internet sebagai alat pemasaran.

- Dari sisi kuantitas, belum dapat melibatkan lebih banyak tenaga kerja karena keterbatasan kemampuan menggaji.

- Karena pemilik UMKM masih sering terlibat dalam persoalan teknis, sehingga kurang memikirkan tujuan atau rencana strategis jangka panjang usahanya.

Untuk mengatasi berbagai permasalahan di atas maka kegiatan Pengabdian kepada Masyarakat $(\mathrm{PkM})$ ini adalah melakukan kegiatan penyuluhan dan workshop, dimana topik yang diangkat adalah tentang pelatihan akuntansi biaya dan teknik pemasaran digital. Topik ini diambil agar pelaku UMKM maupun masyarakat yang baru memulai usaha karena terdampak COVID-19 mendapatkan wawasan tentang cara mengendalikan dan mencatat biaya produksi, serta dapat menjangkau pangsa pasar yang lebih luas dengan desain promosi yang lebih menarik dan teknologi digital marketingnya.

A. Identifikasi dan Perumusan Masalah

Aspek Keuangan : Keterbatasan masyarakat untuk keluar rumah yang sebanding dengan meningkatnya daya beli dan menurunnya keuangan, membuat masyarakat harus berpikir untuk 
Aspek Hukum $\quad$ : Ketidakmampuan masyarakat dalam memenuhi kebutuhan hidup dimasa pandemi ini membuat mereka melakukan segala usaha baik dengan cara yang positif maupun yang negatif. Usaha yang dilakukan dengan cara negatif dapat dikenai konsekuensi hukum

Aspek Kesejahteraan : Bagi beberapa masyarakat, tidak adanya pemasukan Masyarakat tambahan dapat menyebabkan terhambatnya kegiatan atau usaha yang dilakukan dan secara langsung dapat berdampak pada Kesehatan mental dan fisik

Aspek Teknologi : Masyarakat tidak menyadari bahwa dengan alat yang terbatas mereka dapat menghasilkan uang tambahan sebagai solusi dari pandemi COVID-19

B. Tujuan Kegiatan

Tujuan kegiatan ini adalah memberikan edukasi dan praktek langsung tentang bagaimana cara mengolah keuangan bisnis, Teknik pemasaran yang dapat digunakan, dan mengajarkan cara membuat desain promosi yang menarik minat pembeli.

C. Manfaat Kegiatan

1. Sebagai wujud dari tridarma perguruan tinggi dosen yaitu salah satunya Pengabdian Kepada Masyarakat

2. Dosen diharapkan dapat menambah kemampuan soft skill maupun hard skill dari praktek atau interaksi secara langsung dengan masyarakat

3. Membuka lapangan pekerjaan atau peluang usaha bagi masyarakat dengan menggunakan teknologi yang telah ada dan mudah didapatkan.

4. Membuka wawasan masyarakat dalam mengolah keuangan bisnis yang berdampak pada pengolahan bisnis yang lebih terkontrol

5. Mengembangkan kegiatan ekonomi lokal dan pemberdayaan masyarakat guna menciptakan neraca perkenomian yang meningkat

D. Ruang Lingkup Kegiatan

1. Kegiatan dilaksanakan secara online menggunakan Zoom Meeting

2. Peserta yang menjadi target adalah pelaku UMKM lama dan yang baru

3. Peserta dibatasi maksimum 30 orang

4. Peserta tidak dibatasi usia dan telah memahami cara menggunakan perangkat komputer dengan baik khusus untuk workshop desain

5. Kegiatan PkM dilakukan dalam 2 sesi, sesi pertama pada tanggal 22 Agustus 2020 tentang Akuntansi Biaya Produk dan Teknik Pemasaran Digital. Sesi kedua pada tanggal 12 September 2020 tentang workshop desain promosi

6. Instansi mitra yang terlibat dalam PkM ini adalah Babastudio.com dan PemKot Depok

E. Kerangka Pemecahan Masalah

Tabel 1. Kerangka Pemecahan Masalah

\begin{tabular}{lll}
\hline \multicolumn{1}{c}{ Aspek } & \multicolumn{1}{c}{ Masalah } & \multicolumn{1}{c}{ Solusi } \\
\hline Aspek & Keterbatasan masyarakat untuk & 1. Memberikan ilmu tentang \\
Keuangan & keluar rumah yang sebanding & pemasaran digital untuk \\
& dengan meningkatnya daya beli dan & memperluas pasar, serta \\
& menurunnya keuangan, membuat & memberikan ilmu tentang teknik \\
& masyarakat harus berpikir untuk & desain promosi untuk \\
& mendapatkan penghasilan tambahan & meningkatkan daya Tarik pembeli
\end{tabular}


Aspek Hukum

Aspek Kesejahtera an Masyarakat

Aspek Teknologi
Ketidakmampuan masyarakat dalam memenuhi kebutuhan hidup dimasa pandemi ini membuat mereka melakukan segala usaha baik dengan cara yang positif maupun yang negatif. Usaha yang dilakukan dengan cara negatif dapat dikenai konsekuensi hukum Bagi beberapa masyarakat, tidak adanya pemasukan tambahan dapat menyebabkan terhambatnya kegiatan atau usaha yang dilakukan dan secara langsung dapat berdampak pada Kesehatan mental dan fisik Masyarakat tidak menyadari bahwa dengan alat yang terbatas mereka dapat menghasilkan uang tambahan sebagai solusi dari pandemi COVID19
2. Memberikan ilmu tentang akuntansi biaya untuk pelaku UMKM baru dan yang lama untuk mengontrol keuangan usaha Memberikan informasi usaha yang positif dan terhindar dari konsekuensi hukum

Memberikan kegiatan yang menyenangkan hati dan pikiran sebagai bentuk relaksasi

1. Memberikan pelatihan Teknik pemasaran digital dengan memanfaatkan social media dan web browser

2. Memberikan pelatihan membuat desain promosi menggunakan software Paint Tool Sai Ver.1

F. Khalayak Sasaran Antara

- Sasaran PkM ini secara langsung adalah para pelaku UMKM dan orang yang berkeinginan kuat untuk membuka alternatif usaha baru sebagai pengasilan tambahan pada masa Pandemi COVID-19

- Sasaran tidak langsung atas PkM ini adalah masyarakat Indonesia yang berlaku sebagai pembeli

\section{METODE}

Kegiatan PkM ini dilaksanakan menjadi 2 sesi selama 3 jam per hari, dimana sesi pertama dilakukan tanggal 22 Agustus 2020 dan sesi kedua dilakukan tanggal 12 September 2020. Dokumentasi kegiatan PkM ini dapat dilihat pada Link Youtube berikut:

a. Sesi 1 : bit.ly/pkmFTUP_informatika

b. Sesi 2 : bit.ly/PkmInformatika_2

Gambar 1 berikut menunjukkan gambaran kegiatan yang sedang berlangsung.

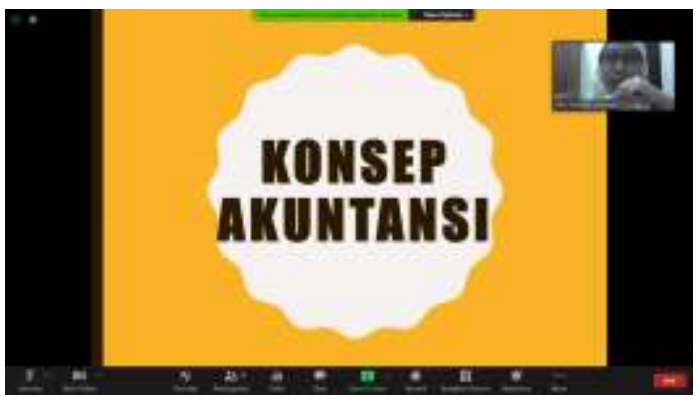

(a)

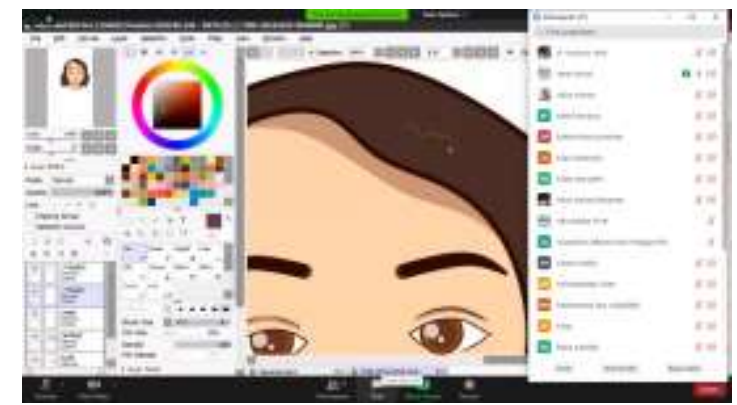

(b)

Gambar 1. Capture Paparan (a) Sesi 1 (b) Sesi 2 
Secara garis besar terdapat 3 hal yang disampaikan kepada pelaku UMKM. Alur kegiatan tersebut dapat dilihat pada Gambar 2 berikut.

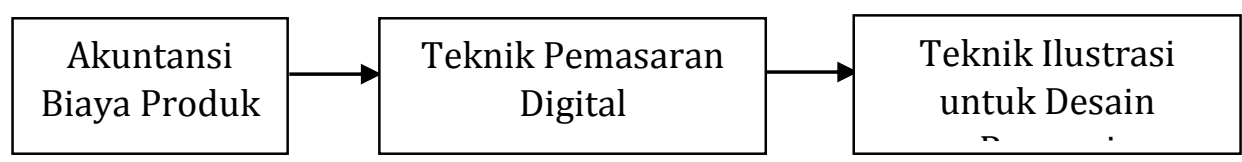

Gambar 2. Alur Kegiatan PkM

\section{A. Akuntansi Biaya Produk}

Akuntansi biaya menyediakan informasi yang dibutuhkan oleh akuntansi manajemen dan akuntansi keuangan. Akuntansi biaya mengukur, menganalisis dan melaporkan informasi keuangan dan non keuangan yang terkait dengan biaya perolehan atau penggunaan sumber daya dalam suatu organisasi (Dewi dan Kristant0, 2013). Sebagai contoh, menghitung biaya produk adalah salah satu kegunaan dari akuntansi biaya (Mulyadi, 2014). Pemberian informasi tentang akuntansi biaya dilakukan diawal karena untuk memberikan gambaran mengenai berapa harga produk yang akan dijual sebelum dilakukannya pemasaran. Hal ini untuk melihat apakah harga yang ditawarkan sudah sesuai dan memenuhi seluruh komponen yang dikeluarkan dan komponen yang ingin didapatkan. Pada pelatihan ini, para pelaku UMKM diajarkan menghitung harga pokok produksi yang meliputi biaya produksi, biaya administrasi, dan biaya pemasaran. Selain itu pelatihan ini pula mengajarkan cara menghitung harga pokok penjualan dan pembuatan laporan laba-rugi.

\section{B. Teknik Pemasaran Digital}

Setelah diberikan pengetahuan tentang harga produk, maka selanjutnya pelaku UMKM diminta untuk belajar mengoptimasi penjualan menggunakan teknik pemasaran digital. Teknik pemasaran digital sendiri merupakan kegiatan yang memiliki lingkup yang lebih luas karena mengacu pada media digital seperti web, e-mail, dan media nirkabel, tetapi juga meliputi pengelolaan data pelanggan digital, dan juga bagaimana Internet dapat digunakan bersama dengan media tradisional untuk memperoleh dan memberikan layanan kepada pelanggan (Chaffey, dkk, 2009).

Ada 2 jenis teknik pemasaran digital yaitu push digital marketing dan pull digital marketing (Sanjaya, dkk, 2009). Push digital marketing lebih dikenal sebagai kegiatan promosi yang tidak membutuhkan ijin dari pembeli. Para penjual bisa memasukkan apa saja ke dalam media promosinya. Contoh kegiatan ini adalah beriklan melalui blog, website sendiri, website lain yang disediakan secara gratis, dan melalui email. Sedangkan pull digital marketing lebih mengarah kepada pencarian aktif oleh pembeli terhadap suatu produk. Sehinga Teknik Search Engine Optimization (SEO) sangat dibutuhkan oleh jenis ini.

Pada kegiatan PkM ini, ada 3 teknik yang diajarkan yaitu SEO, Social Media Marketing dalam hal ini studi kasus adalah Facebook, dan Pay-per-click menggunakan Google-Ads dimana alurnya dapat dilihat pada Gambar 3 berikut.

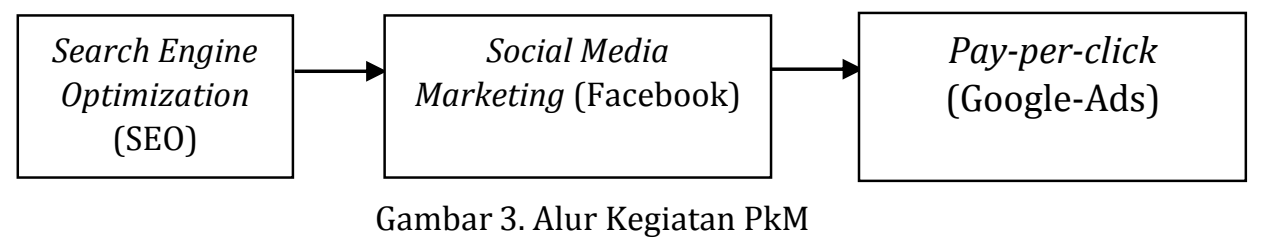

Tips dan trik SEO :

1. Daftarkan Website ke Google Search Console

2. Pasang Google Analytics 

3. Buat Sitemap XML
4. Tingkatkan Kecepatan Website
5. Buat website Mobile Friendly
6. Daftar Google My Bisnis
7. Tambahkan SSL atau HTTPS
8. Riset Keyword
9. Gunakan Long Tail Keyword
10. Buat Konten yang Lengkap dan memberikan informasi yang Jelas
11. Buat judul atau meta Title dan Deskripsi yang menarik
12. Tambahkan Internal link di setiap Artikel atau page
13. Tambahkan Alt tag untuk gambar
14. Tambahkan Plugin Share Sosial Media
15. Hapus Backlink spam

Meningkatkan kualitas iklan Agar Iklan di halaman Utama :

1. Buat grup iklan yang sangat spesifik

2. Gunakan kata kunci yang tepat. Penggunaan 2 - 3 kata akan lebih efektif jika dibandingkan hanya menggunakan 2 kata saja

3. Tambahkan kata Kunci pada judul dan deskripsi Iklan

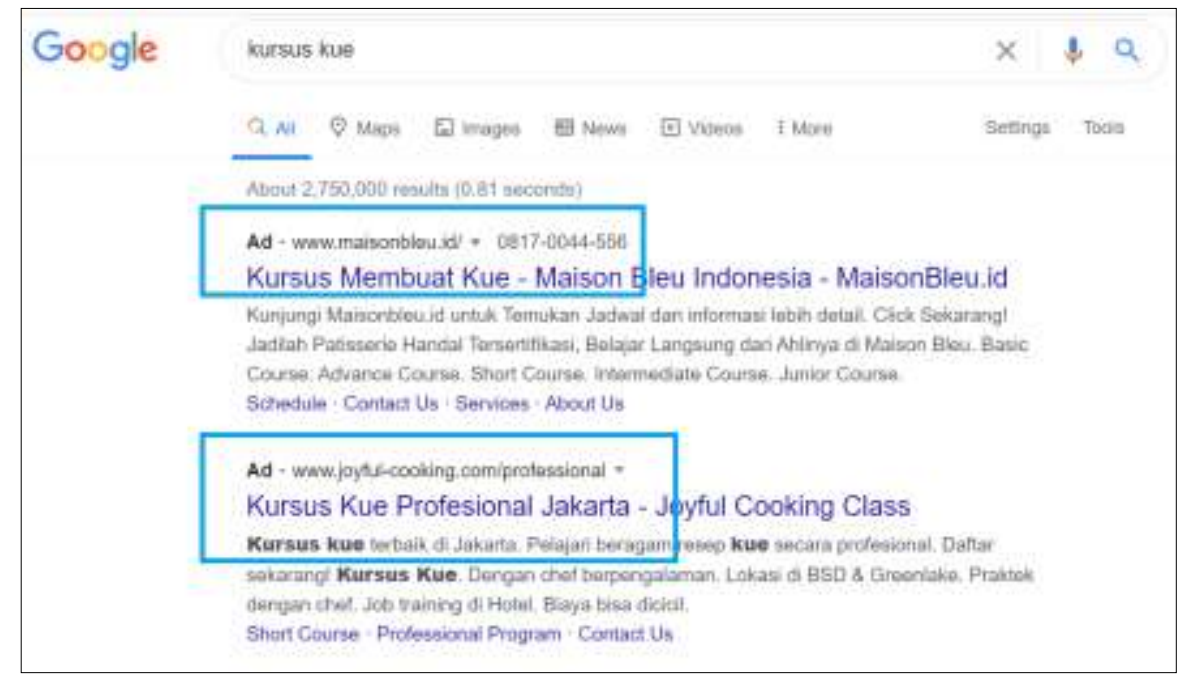

Gambar 4. Contoh Penerapan Kata Kunci untuk Deskripsi Iklan

4. Gunakan pesan ajakan (CTA) yang meyakinkan. Teks iklan Anda harus memiliki pesan ajakan yang meyakinkan. Pesan ajakan akan mendorong pengguna mengklik iklan dan membantu mereka memahami apa yang dapat mereka lakukan setelah menjangkau halaman landing Anda. Berikut ini beberapa contoh kata-kata pesan ajakan: Beli, Jual, Pesan, Jelajahi, Temukan, Daftar, Coba, Dapatkan Penawaran.

5. Terapkan setidaknya 3 ekstensi untuk setiap kampanye/grup iklan

\section{HASIL DAN PEMBAHASAN}

Hasil

Evaluasi telah dilakukan dengan menyebarkan kuisioner secara langsung yang dikembalikan ketika acara selesai dengan hasil yang disajikan sebagai berikut. Sebanyak 27 responden yang diberikan link lembar kuesioner, hanya 24 responden yang mengembalikan kuesioner pada sesi 1 dan dari sebanyak 18 responden pada sesi 2, hanya 16 orang yang memberikan feedback. Tabel 2 berikut adalah hasil kuesioner dari PkM ini. 
Tabel 2. Rekap Hasil Kuesioner

\begin{tabular}{|c|c|c|}
\hline No & Daftar Pernyataan & Kesimpulan Hasil Kuesioner \\
\hline 1 & $\begin{array}{l}\text { Sebanyak } 70,8 \% \text { responden } \\
\text { memiliki minat untuk belajar } \\
\text { desain promosi }\end{array}$ & \\
\hline 2 & $\begin{array}{l}\text { Sebanyak } 58,3 \% \text { responden } \\
\text { menggunakan Instagram } \\
\text { sebagai media yang efektif } \\
\text { untuk melakukan penjualan }\end{array}$ & 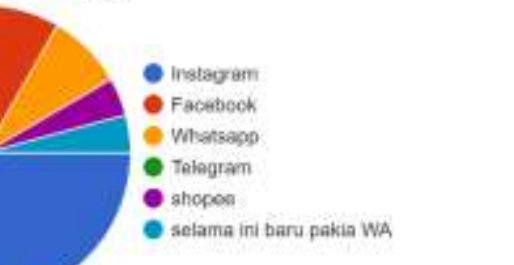 \\
\hline 3 & $\begin{array}{l}\text { Sebanyak } 95,8 \% \text { responden } \\
\text { menggunakan Whatsapp } \\
\text { sebagai media komunikasi } \\
\text { chat dengan pembeli }\end{array}$ & $\begin{array}{l}\text { - Whatsapp } \\
\text { Line } \\
\text { - Telegram } \\
\text { Facebook Messenger } \\
\text { instagram DAM }\end{array}$ \\
\hline . & $\begin{array}{l}\text { Sebanyak } 41,7 \% \text { responden } \\
\text { merasa kesulitan untuk } \\
\text { berkomunikasi } \\
\text { membangun dan } \\
\text { pembeli }\end{array}$ & 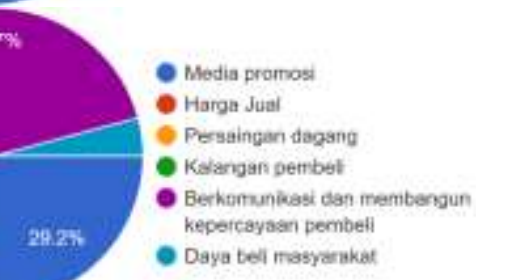 \\
\hline 5 & $\begin{array}{l}\text { Sebanyak } 62,5 \% \text { responden } \\
\text { menyisihkan } r \text { Sebagian } \\
\text { penghasilan untuk kegiatan } \\
\text { promosi }\end{array}$ & \\
\hline 6 & $\begin{array}{l}\text { Sebanyak } 87,5 \% \text { responden } \\
\text { sudah memiliki target pasar } \\
\text { yang sesuai dengan barang } \\
\text { yang ditawarkan }\end{array}$ & $\begin{array}{l}\text { - Seusai } \\
\text { - Betum sesuai }\end{array}$ \\
\hline 7 & $\begin{array}{l}\text { Sebanyak } 45,8 \% \text { responden } \\
\text { lebih memilih untuk } \\
\text { menggunakan jenis transaksi } \\
\text { cash on delivery (COD) }\end{array}$ & 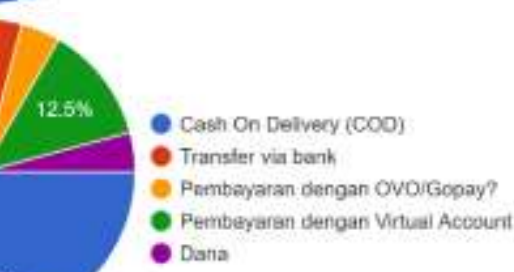 \\
\hline
\end{tabular}


8 Peringkat media yang paling banyak digunakan UMKM untuk berjualan adalah :
a. Whatsapp
b. Instagram
c. Facebook
d. Tokopedia
e. Shopee

9 Sebagian besar pembeli yaitu sebanyak $62,5 \%$ masih berasal dari orang yang dikenal pada kehidupan nyata

10 Sebagian besar responden menyatakan bahwa promosi yang efektif adalah menampilkan gambar produk asli dan memberikan promo atau potongan harga. Sedangkan promosi dengan menggunakan animasi, gambar, atau kartun hanya disukai oleh sebanyak $25 \%$ responden

11 Sebanyak 43,5\% responden menyatakan bahwa awal bulan dan hari khusus seperti hari raya adalah masa dimana banyak pembeli yang melakukan transaksi
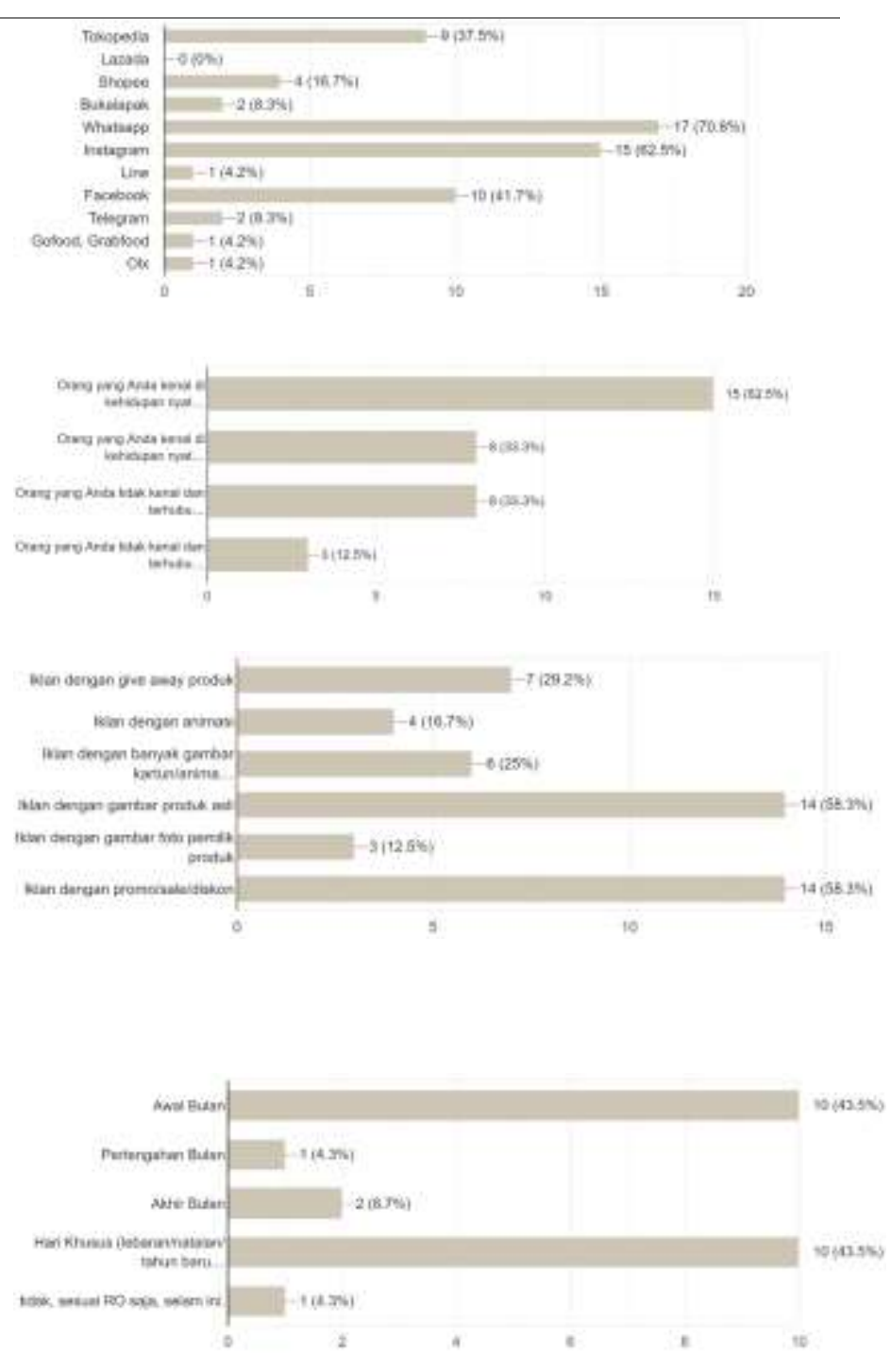

Pembahasan

Berdasarkan hasil kuesioner yang diperoleh, diketahui bahwa rata-rata pembeli berasal dari orang yang dikenal pada kehidupan nyata. Kemudian, media sosial yang paling banyak digunakan untuk berjualan adalah Instagram, kemudian posisi kedua ditempati oleh Facebook. Alasanya kedua media sosial ini dirasa cukup mudah digunakan, banyak teman atau relasi yang melihat, serta memiliki banyak pengguna. Namun disisi lain, untuk memberikan respon langsung kepada pembeli, sebanyak 70,8\% pelaku UMKM masih menggunakan fitur chat dari Whatsapp. Sedangkan untuk web penyedia jasa jualan seperti Tokopedia dan Shopee masih belum menjadi prioritas, karena dirasa lebih kompleks untuk melakukan unggah dan pemberian informasi produk. Kemudian sebanyak 45,8\% pelaku UMKM lebih menyukai sistem pembayaran dengan metode COD, hal ini dikarenakan banyak pembeli yang tidak memiliki fasilitas ATM, internet maupun mobile banking.

Dari hal-hal tersebut, maka dapat ditarik kesimpulan bahwa rata-rata pelaku UMKM sudah mengetahui hal positif dari penggunaan media sosial sebagai media penjualan. Namun Langkah yang diterapkan dirasa kurang maksimal untuk mendapatkan respon pembeli. Hal ini diketahui dengan banyaknya pembeli yang berasal dari orang-orang yang dikenal dikehidupan nyata. Selain itu, nama toko atau brand yang diciptakan serta variasi produk yang ditawarkan terlalu banyak sehingga belum terlihat ciri atau karakteristiknya. Untuk itu, melalui pelatihan ini sedikit demi sedikit diberikan wawasan serta praktek langsung tentang bagaimana cara 
mengoptimalisasi penjualan sehingga pembeli tidak hanya dari kalangan yang terbatas saja. Pada pelatihan ini diajarkan pula cara mengiklankan produk melalui fasilitas yang telah disediakan dari media sosial seperti facebook. Tidak hanya itu, pada pelatihan ini diajarkan pula cara meningkatkan pencarian melalui media search engine seperti Google serta tips dan triknya.

Namun demikian, karena keterbatasan ruang maka pelatihan ini dirasa kurang maksimal. Karena sempat terjadinya gangguan jaringan dan rata-rata pelaku UMKM adalah ibu rumah tangga yang memiliki keterbatasan waktu. Untuk itu pada program lanjutan dan pada kondisi yang telah memungkinkan, perlu diadakannya praktek secara offline sesuai dengan respon yang diberikan oleh peserta pelatihan.

\section{KESIMPULAN}

Kegiatan PkM ini diangkat untuk membantu kondisi perekonomian Indonesia yang tidak stabil karena Covid 19. Dilihat dari sudut pandang ini, banyak pekerja yang dirumahkan bahkan mendapatkan Pemutusan Hubungan Kerja (PHK). Keterpurukan menghadapi wabah Covid 19 dapat diselesaikan dengan meningkatkan kesejahteraan bagi ekonomi bisnis. Salah satu langkah yang bisa dilakukan adalah membuka peluang usaha baru, usaha kreatif, dan menjadi pelaku Usaha Mikro, Kecil dan Menengah (UMKM). Sebagai seorang akademisi yang memiliki kemampuan Hardskill yang baik, maka solusi yang ditawarkan adalah memberikan wawasan dan praktek langsung tentang kegiatan usaha tersebut. Pemberian wawasan dilakukan dengan memberikan ilmu tentang akuntansi biaya yang erat kaitannya dengan menghitung harga jual produk sebelum dipasarkan, serta mengajarkan cara membuat laporan laba dan rugi. Tidak hanya itu, pelaku UMKM juga mendapatkan wawasan dan pelatihan tentang cara memasarkan produknya secara digital. Pemilihan Teknik digital dilakukan karena saat ini hampir semua lini kehidupan menggunakan handphone dalam aktifitas sehari-hari. Celah ini pula yang diambil untuk mendapatkan jangakauan pasar yang lebih luas.

\section{UCAPAN TERIMA KASIH}

Penulis mengucapkan terima kasih kepada Fakultas Teknik Universitas Pancasila yang telah memberi dukungan financial terhadap pengabdian ini. Tidak lupa pula penulis ucapkan terima kasih kepada Babastudio.com dan PEMKOT Depok selaku instansi mitra yang ikut berkontribusi pada kegiatan ini.

\section{DAFTAR PUSTAKA}

Chaffey, D., Chadwick, F.E., Johnston, K., \& Mayer, R. (2009). Internet marketing: strategy, implementation and practice (4th edition). Pearson Education: Prentice Hal.

CNBC. (2020). 3 Bulan Corona, 3 Juta Orang Kena PHK \& Dirumahkan. Retrieve November 1, 2020, from https://www.cnbcindonesia.com/news/20200603193109-4-162890/3bulancorona-3-juta-orang-kena-phk-dirumahkan

Dewi, S.P., \& Kristanto, S.B. (2013). Akuntansi Biaya. Bogor : In Media. https://www.researchgate.net/publication/305730602_AKUNTANSI_BIAYA/link/579e3e89 08ae5d5e1e171519/download

Lembaga Pengembangan Perbankan Indonesia dan Bank Indonesia. (2015). Profil Bisnis Usaha Mikro, Kecil, dan Menengah (UMKM). Retrieve November 1, 2020, from https://bi.go.id

Mondol, S., \& Mohiuddin, M. G. (2020). Confronting Covid-19 with a paradigm shift in teaching and learning: A study on online classes. International Journal of Social, Political and Economic Research, 7(2), 231-247.

Mulyadi . (2014) . Akuntansi Biaya. Edisi-5. Yogyakarta: Universitas Gajah Mada.

Pakpahan, A. K. (2020). Covid-19 Dan Implikasi Bagi Usaha Mikro, Kecil, Dan Menengah. Jurnal Ilmiah Hubungan Internasional, 59-64. 
Sanjaya, R. \& Josua, T. (2009). Creative Digital Marketing. Jakarta : PT Elex Media Komputindo. Sarfiah, S.N., Atmajaya, S.E., \& Verawati, D.M. (2019). UMKM Sebagai Pilar Membangun Ekonomi $\begin{array}{lllll}\text { Bangsa. Riset } & \text { Ekonomi }\end{array}$ https://jurnal.untidar.ac.id/index.php/REP/article/view/1952

Rahmi, V.A., Ismanto, H., \& Fathoni, M.Z. (2020). Inovatid saat Pandemi Covid "Pelatihan Kewirausahaan khas Perempuan Berbahan Sampah Kolaborasi BUMDes". Jurnal Pengabdian Kepada Masyarakat DINAMISIA, 4(3), 418-425. 